\title{
Mesenchymal Stromal Cells; Role in Tissue Repair, Drug Discovery and Immune Modulation
}

\author{
Karen English ${ }^{1 *}$, Bernard P. Mahon ${ }^{1}$ and Kathryn J. Wood ${ }^{2}$ \\ ${ }^{I}$ Cellular Immunology Laboratory, Institute of Immunology, National University of Ireland Maynooth, Maynooth, Co. \\ Kildare, Ireland; ${ }^{2}$ Transplantation Research Immunology Group, Nuffield Department of Surgical Sciences, John Rad- \\ cliffe Hospital, University of Oxford, OX3 9DU, UK
}

\begin{abstract}
Mesenchymal stromal cells (MSCs) participate in repair of damaged tissues, possess the potential to serve as a useful tool in the drug discovery field and exert immunosuppressive effects as demonstrated by their ability to modulate the immune response. Herein, the roles played by MSC differentiation and/or production of trophic factors involved in tissue repair are discussed. MSCs offer the opportunity to probe targets that conventional or differentiated cell lines do not express; thus providing a more refined system that allows identification of novel therapeutics. However, there are difficulties associated with drug discovery assays to which MSCs are not exempt. The immunosuppressive potential of MSCs has already been utilised in clinical trials where MSCs have been used to treat patients with graft- versus- host disease (GvHD) and autoimmune diseases. Another possible therapeutic application of MSCs lies in the field of transplantation tolerance. Although the capacity of MSCs to modulate immune responses has received much attention, the role of MSCs in transplantation tolerance is as yet unclear. In this review, we discuss the evidence for MSC induction of a state of tolerance in the transplantation setting.
\end{abstract}

Keywords: Mesenchymal stem cells, Mesenchymal stromal cells, Tissue repair, Drug discovery, Transplantation tolerance.

\section{TISSUE REPAIR AND REGENERATION}

In evolutionary terms, the appearance of multicellular organisms with specialised tissues and organs created a profound challenge; the need to regenerate or restore damaged tissue. Tissue regeneration is the solution to this problem and is seen most dramatically in amphibians [1,2]. Here physiological damage can induce a regenerative process that restores both organ architecture and function. The fields of regenerative medicine and human tissue engineering seek to harness the mammalian counterparts of such processes for therapeutic use in humans. In mammalian systems studied to date, such processes rely on a complex interaction of nondifferentiated cells and trophic factors at the site of damage $[3,4]$. The precise nature of such complex interactions varies by disease/injury, target organ, species, age and other parallel reparative processes. These processes may involve dedifferentiation of damaged tissue, trans-differentiation of progenitor cells, cell fusion, or differentiation of precursor stem cells [3]. As tissue resident and bone marrow derived stem and progenitor cells can contribute to regeneration, cells such as bone marrow derived mesenchymal stem cells (MSCs) have become a major feature of regenerative medicine, and the basis of a rapidly growing industrial sector based on cell therapy $[5,6]$.

\footnotetext{
*Address correspondence to this author at the Cellular Immunology Laboratory, Institute of Immunology, National University of Ireland Maynooth, Maynooth, Co. Kildare, Ireland; Tel: +353 17085350; Fax: +353 1 7086337; E-mail karen.english@nuim.ie
}

\section{MSC History, Source and Characteristics}

The term "mesenchymal stem cell" was coined by Caplan in 1991 [7,8] referring to the cells characterised by Friedenstein as bone marrow derived, plastic adherent cells with trilineage differential potential $[9,10]$. It is perhaps worth recollecting the differences between stem cells and committed progenitor cells. Stem cells have extended capability for self renewal, are telomerase positive and so not constrained by the Hayflick limit and can form all the cell types associated with the source germ layer lineage (whether ecto-, meso or endo-dermal). In contrast, progenitor cells have a finite lifespan confined by Hayflick's limit (often $<70$ cell doublings) and in general more limited capacities for differentiation (from unipotency to multipotency) [2]. Given this distinction, MSCs are probably more accurately described as multipotent mesenchymal stromal cells, progenitor cells closely related to the more plastic multipotent adult progenitor cells (MAPCs) [11,12], as well as "marrow isolated adult multilineage inducible cells" (MIAMI cells) $[13,14]$ and multipotent adult stem cells (MASCs) [15]. For the remainder of this review we will consider only MSCs. These cells can be isolated not only from bone marrow but also the dermis, dental pulp, lung, thymus, trabecular bone, and readily from adipose tissue and umbilical Wharton's jelly [5,16-19].

Although much progress has been made, the field is hampered by the absence of specific, unique, identifying markers of MSCs and thus the International Society for Cell Therapy (ISCT) definition of MSCs has become an important consensus point -this defines multipotent MSCs as plas- 
tic-adherent cells (under standard culture conditions) that express CD73, CD90 and CD105 but not the hematopoietic markers CD11a, CD19, CD34, CD45, or HLA-DR [20,21]. In addition to qualify as MSCs, isolated cells should demonstrate the capacity to differentiate into osteocytes, adipocytes, and chondrocytes in vitro when suitably stimulated $[20,21]$. It is important that researchers in drug discovery or research programs adhere to rigorous quality control regarding MSCs, as populations can lose multipotency with passage $[22,23]$. Even so, it is likely that the ISCT definition allows groups to work with heterogenous populations that may include mixtures of genuine stem cells with other cells that are more likely committed progenitors, perhaps accounting for variability in some published data. More seriously, groups which fail to repeatedly monitor for hematopoietic contamination may be generating data of little value. While MSCs from different sources share differentiation capacity (adipocytes, osteoblasts and chrondrocytes) as well as phenotypic markers [24], more rigorous functional assays have identified clear differences in function. In particular, MSC derived from bone marrow and synovium were more effective in inducing repair in cartilage defect models than those from adipose or skeletal muscle [25]. Importantly, MSC derived from dental pulp but not those derived from adipose or bone marrow generate dentin [26]. Whereas the capacity to differentiate into osteocytes, adipocytes, and chondrocytes are defining features of MSCs in vitro, more potent transdifferentiation has been described. MSCs can be driven to differentiate into myocytes, endothelium, cardiomyocytes, fibroblasts, neural cells, and possibly hepatocytes, epithelium or even insulin producing cells, depending on the stimuli [27-35]. This multipotentiality combined with the ease of culture and expansion, have led to MSCs becoming a lead therapeutic in the race for cell based regenerative therapies $[6,36]$.

\section{Tissue Repair Through Direct Differentiation or Trans- differentiation}

MSCs have been used as regenerative cell therapies in numerous experimental models. For example, site directed administration of bone marrow MSCs to infarcted myocardium resulted in the regeneration of the injured tissue [3740]. Furthermore mouse MSCs delivered into healthy adult myocardium resulted in the formation of new blood vessels in which donor cells were identifiable after transplantation $[41,42]$. Transplanted MSCs had differentiated in situ to several cell types including cardiomyocytes, endothelial cells, pericytes and smooth muscle cells [41]. Using single cell marking this group also showed that cardiomyocytes were most likely to have been generated stochastically from a single-cell-derived stem cell [42]. Similarly, in porcine models, MSCs have been shown to engraft into the host myocardium and differentiated to myogenic cells, reduce infarct size, and support other physiological improvements [43]. These observations are supported by studies suggesting that MSCs can engraft in vivo in bone, lungs, and liver [11,44-46], and that MSCs (in demineralised bone or other matrices) contribute to bone growth and repair [47-49]. In rodent models of acute renal failure, male MSCs protected female recipients from induced pathology and male cells were not only localized to tubular epithelium but also expressed characteristic lectins [50,51], these and other studies support local engraftment and differentiation into tubular epithelial cells.

MSCs can contribute to regeneration of ectodermal, mesodermal and endodermal tissues (reviewed in [52]), however these effects might be attributable to mechanisms other than differentiation. Indeed, the evidence for true MSC engraftment and direct reconstitution by MSC differentiation in vivo is currently not extensive despite the vast literature on these cells. Even in myocardial infarction models, both the level of engraftment and the number of MSC derived cardiomyocytes seems to be too low to fully explain the therapeutic benefit, and likewise the beneficial effects of MSCs in acute ischemic renal disease models appears to be through differentiation-independent mechanisms [53-57].

\section{Tissue Repair Mediated by Trophic Factors}

A conceptual advance in this debate came when it was proposed that much of the therapeutic benefit of MSCs was associated with the release of soluble factors that acted in a paracrine manner to promote repair $[58,59]$. Thus MSCs might be considered as trophic agents, which guide or "nourish" the process of tissue repair rather than, or in addition to, direct differentiation and regeneration. Of course if MSCs are heterogeneous mixed populations, it is possible that trophic action and differentiation are not mutually exclusive, or that different trophic effects may be performed by different sub-populations. The term "trophic effect" encompasses many functional characteristics of MSCs such as immunomodulation (see below) as well as anti-apopototic, cytoprotective effects and the promotion of angiogenesis [58]. The latter may be an important component of repair as it is known that vascular stability contributes to healing and that pericytes (mural cells) contribute to this [60]. Interestingly, MSCs express some pericyte markers and it has been proposed that tissue resident MSCs may be derived from perivascular precursors $[16,47,61,62]$. MSCs can also express VEGF [63] and therefore may be intimately involved in neovascularisation of wounds and suggesting this to be a key trophic contribution to regeneration.

\section{Effect of Licensing on MSC Potency}

There is still a great deal to be discovered about the regenerative process and the role of MSCs. Indeed much may still be learned from comparative systems in amphibians and other animals $[1,2,4]$. These and other studies have shown that regeneration requires tissue resident stem cells of different potency and type supported by complex trophic factors at the site of damage. A process that is more subtle and broad than current models of MSC regeneration. Perhaps most interesting is the demonstration by Lucas et al that the inflammatory process (linked to tissue damage) characterised by neutrophil and macrophage influx, was essential to regeneration (reviewed in $[1,2]$ ). These studies indicated that a complex mixture of progenitor cells (including fibrogenic and myofibrogenic progenitors, lineage committed stem cells and uncommitted pluripotent stem cells) were involved in the process. Inflammation was important for debridement and reserve/stem cell activation [1,2]. This is strikingly similar to the concept of "licensing" that has been proposed for mouse and human MSCs. Licensing suggests that MSCs are acti- 
vated and enhanced by inflammatory signals such as IFN- $\gamma$ at the site of repair and that such licensing enhances the regenerative process [64]. This is supported by data from numerous groups showing that inflammatory mediators generally do not break the immunosuppressive nature of MSCs but rather enhance it [65-69]. The implication being that future cell therapy may benefit from pre-stimulation of MSCs.

The trophic influence of MSCs is likely to extend to other aspects of the repair process as well. For example, MSCs have a profound suppressive influence on fibrosis in vivo [70,71]. This may well be linked to the observation that human and mouse MSCs express the anti-fibrotic factor HGF and this is also upregulated by IFN- $\gamma$ prestimulation/licensing $[55,64,68,72]$. Clearly MSCs play a complex role in tissue repair and these roles are achieved via multiple mechanisms. Overall regeneration and engraftment probably play a much smaller part than previously anticipated in the regenerative processes mediated by MSCs. Indeed features such as the anti-fibrotic effect and the powerful immune modulation that can be achieved by MSCs suggest that cell therapies using these cells may find most success against targets such as the chronic autoimmune diseases. However, it is important to note that MSC therapy is not a panacea. In particular the influence of MSCs on fibrosis will require further study as MSCs can also express pro-fibrotic factors or promote fibrogenesis indirectly through differentiation into myofibroblasts [73]. Moreover MSC associated immune suppression can provide increased risk of infection in patients as has been documented in GvHD trials [74].

\section{DRUG DISCOVERY}

Current drug discovery programs rely on early stage, high throughput, hit identification protocols based on in vitro models. Indeed cell based in vitro systems contribute to hit identification, target validation, lead selection, as well as informing protocols around ADME-Tox. The disappointing late stage attrition of leads suggests that more refined approaches are now required [75]. Most current drug discovery systems are based on established transformed cell lines or specific primary cultures. Such lines have proved useful in addressing questions of pharmacological performance and safety, having the great advantage of near limitless scalability. However these cell systems are of abnormal genotype (neoplastically transformed), are tissue lineage restricted, show abnormal physiological and growth characteristics and it is not surprising that stem cell approaches are being examined to improve these programs and to enhance the discovery process [75].

\section{Advantages of MSC based Drug Discovery Platform}

Certainly, the greatest drug discovery potential lies in 'pluripotent' human embryonic stem cells (hESCs) and in human somatic cells that have been reprogrammed into induced pluripotent stem cells (iPSCs) with embryonic stem cell properties [75-78]. Drug discovery based on these cells is likely to become a main stream component of all pharmaceutical discovery strategies in the near future [77-80]. Indeed MSC based approaches are already in use [81-83] and have major advantages over conventional non-candidate based hit identification programs. MSCs are not transformed, have less restricted lineage limitations, and display more relevant growth/ cell division characteristics [7,59]. In particular the expandability of umbilical cord MSCs derived from Wharton's jelly make these cells good candidates for inclusion in high throughput screening (HTS) systems $[18,52]$. The current applications for MSCs are in compound screens, to probe structure-activity relationships, in the conversion of hits to leads and in supporting or terminating the progression of lead molecules through the development process. This is particularly relevant to discovery programmes aimed at the development of treatments for osteoporosis, obesity, diabetes, metabolic disorders and joint disease, where MSCs provide an opportunity to deliver more targets and process appropriate information. In addition MSC screens may play an important role in the discovery of drugs targeting cancer stem cells or the tumour stroma $[84,85]$.

MSC based drug discovery protocols offer opportunities and advantages in two broad areas. The first area concerns targets that are currently difficult to assess. It is necessary to appreciate that certain drug targets may only be expressed at specific times during lineage development or in minority tumour tissue residents. MSCs offer an opportunity to probe such targets at specific differentiation stages whereas conventional or differentiated cell lines do not without extensive manipulation. Thus MSCs offer a more refined and sophisticated system that allows identification of small molecules acting at unique stages of the differentiation process, and/or validation of more subtle (but potentially more relevant) targets $[79-80,86]$. The second area concerns the exploitation of the immune modulatory aspects of MSC biology for drug discovery, an area ripe for exploitation. The major opportunities for drug discovery are associated with two inter-linked disease processes: inflammation and autoimmunity/ transplantation. Inflammation is a key component of the pathological processes of the major diseases requiring new therapies, and targeting inflammation is a major feature of most drug discovery programmes. The potent anti-inflammatory potential of MSC discussed below, allows these cells to be combined with RNAi libraries in high throughput and high content screens, to identify anti-inflammatory candidates and particularly candidate combinations. The use of MSC in drug discovery for novel therapies supporting transplantation or targeting autoimmunity is nascent. However the very recent demonstration that regulatory/tolerogenic $\mathrm{T}$ cells are not only induced by MSC but that such cells are effective and necessary at reducing immune mediated pathology in animal models is important [87]. This suggests that MSC may be a rich source of novel tolerogenic and suppressive factors of real value. In effect MSC might be profitably exploited to discover both candidate drugs and novel mechanisms to promote transplant tolerance or suppress autoimmune and hypersensitivity reactions.

The most likely approaches to develop novel screens will combine MSC with RNAi or antagonist libraries. The combination of MSC based high throughput assays with RNAi libraries allows functional screening to be performed with a high level of complexity [88-90]. A process that offers a rich vein of potential novel hits and leads; however, the assumptions underlying RNAi use in these systems need to be con- 
sidered carefully. The uptake of siRNA, and the efficacy of silencing are likely to be quite variable in such systems. Furthermore the induction of intrinsic cell processes (such as production of type 1 interferons) can confound interpretation. Nevertheless the combination of more informative MSC assay approaches, extensive silencing libraries, and high throughput assay handling offer a powerful drug discovery tool [88-91].

In addition to the MSC based assay system, the choice of readouts needs careful consideration. For differentiation based approaches, these may be relatively straightforward such as the measurement of alkaline phosphatase activity as an early marker of osteogenesis. However the efficient induction of some pathways such as cartilage formation requires MSCs to be cultured in cell pellets, embedded in gels or some other three dimensional matrix. These systems provide additional challenges and may require both large numbers of cells and novel quality control protocols. Nevertheless such approaches have found application in osteoarthritis research, where modulators of early chondrogenic differentiation may be measured by the expression of SOX-9 in MSC pellet cultures [92]. Although not strictly drug discovery, MSC differentiation along the adipogenic pathway [9394] might also be used to probe environmental features of pollutants, environmental screening or bio distribution/accumulation in fatty tissue in ADME studies [95]. MSC derived adipocytes can also be used to screen lipolytic agents, or to assess modifiers of lipid accumulation, supporting discovery of novel therapeutic interventions in obesity and diabetes [95]. The selection of readouts for immunological indicators will also be very dependent on the disease indication of interest. It is quite feasible that if inflammation is the target then MSC approaches can be adapted to the myriad of systems in current use. However future discovery based on tolerance induction or suppressor activity by MSC (discussed below) may well require new high content and high throughput approaches perhaps based on second cell readouts (dendritic cell or regulatory $\mathrm{T}$ cell) or more likely reporter approaches (such as FOX P3 expression).

\section{Limitations of MSC based Drug Discovery Platform}

The benefits of MSC based drug discovery are challenged by two major difficulties: assay reproducibility and robustness, both of which have limited the wider application of MSC based assays [96]. Bone marrow derived MSCs show both donor-to-donor and lot-to-lot variability in proliferation and differentiation potential; features which cause considerable trepidation when designing a drug discovery strategy and this might be especially problematic for immunological indications. Unfortunately the difficulties do not end there, as MSCs defined by the ISCT and isolated by most published protocols are a heterogeneous mixture of similar mesenchymal cells, possibly containing more potent and stem like populations, along with cells with reduced potential, pre-committed to single or dual lineages. Furthermore heterogeneity in populations is compounded by other features of differentiation. For example, even in adipocyte promoting conditions, a considerable percentage (30 -40\%) of cells in a bone marrow derived MSC culture remain undifferentiated $[97,98]$. Whilst these variations in potential pro- vide a system-based robustness to the repair response in vivo, in the context of drug discovery such heterogeneity of response creates serious challenges. Another related difficulty is that differentiation of MSCs to some cells such as cardiomyocytes can be relatively inefficient using current protocols. Thus screening processes need to operate when only small numbers of the specialised cells (signal) are produced against a non-differentiated background (noise) [96].

\section{New Readout Systems}

It is fortunate that recent advances in automated imaging and data processing have allowed the development of multiparameter endpoint quantitation techniques and helped to overcome some of the difficulties outlined above. The most widespread approaches have been termed high content screening (HCS) but may also be known as cell based screening, phenotypic screening or visual screening [88$90,99,100]$. HCS has been used predominantly as a research tool in industrial and academic situations. A basic example of HCS application is the determination of the effect of a potential drug/chemical on aspects of stem cell differentiation and involves the combination of live cell imaging with sophisticated image analysis [86]. This research platform offers the potential to conduct large scale cell based screens in a more physiologically relevant experimental format and allows robust assays to be developed in situations where differentiation involves only a subset of the population exploited. Essentially HCS involves 5 steps, assay optimisation for scale up; image acquisition; automated image analysis, data management, data analysis/hit output.

Although HCS optimisation can be time consuming and complex, once attained, robust, reproducible and informative outputs can be achieved and novel hits obtained [101-103]. Such approaches may seem expensive, but higher quality information obtained early in the discovery process may lead to reduced late stage attrition and higher quality leads, making combined MSC based assays with HCS readouts a feasible platform for novel drug discovery programmes.

\section{MSC IMMUNE MODULATION}

The development of MSCs as therapeutic agents has progressed rapidly over the past 5 years and their potential as modulators of the immune responses has ignited great interest in the field. Currently clinical trials focusing on MSCs for treatment of GvHD and autoimmune diseases are underway. One of the areas likely to benefit from the therapeutic effects associated with MSC immune modulation is that of transplantation [104].

\section{The Impact of MSCs on Transplantation Rejection}

To date transplantation remains the most effective treatment for patients with established organ failure. While significant advances in the development of immunosuppressive drugs has allowed the successful clinical application of organ transplantation, there are problems associated with long term administration of non-specific immunosuppressive drugs including increased susceptibility to infection and induction of diabetes, de novo malignancy, cardiovascular complications and renal failure [105]. Consequently, there is a clear requirement for the development of more specific immuno- 
suppressive therapies that are non-toxic for utilisation in the organ transplantation setting.

A large body of data supports the idea that MSCs can very effectively modulate the immune response both in vitro and in vivo and may therefore serve as a potential source of immunosuppressive therapy [106]. Certainly, data from both pre-clinical models and clinical trials suggest that MSCs have the capacity to modulate the immune response in vivo. However is it not yet clear whether or not MSCs can induce a state of tolerance in the setting of clinical organ transplantation, but the outlook is promising [104].

\section{Influence of MSC on the Innate Immune Response}

The innate immune response provides the first line of defence against infection and encompasses both cellular and non-cellular components including complement activation and the involvement of evolutionarily conserved pathogen recognition receptors (PRRs). In addition, innate immunity is also triggered by danger signals. Although rejection of allogeneic grafts is known to be mediated primarily by $\mathrm{T}$ cell and antibody responses [107,108], a number of studies now suggest that the innate immune response plays a role in the immune response to solid organ transplantation (reviewed in [109]).

MSCs used as a cell therapy in any inflammatory setting including organ transplantation will encounter the innate immune response and therefore it is important that we understand how MSCs will interact with these first line responses. Recently Tu et al have demonstrated that human MSCs inhibit complement activation through secretion of factor $\mathrm{H}$ (the primary complement inhibitor found in serum) [110]. Furthermore, MSCs have been demonstrated to be responsive to the complement activation products $\mathrm{C} 3 \mathrm{a}$ and $\mathrm{C} 5 \mathrm{a}$, leading to migration and activation of MSCs [111]. Clearly, the interactions between MSCs and the complement system require further study, but it seems likely that MSCs are not only protected from deletion by innate mechanisms but are also responsive to such mechanisms; which may be important at sites of tissue injury or ischemia reperfusion injury associated with transplantation.

Toll like receptors (TLRs) are the best studied PRRs and play an important role in activating the innate immune response and subsequent shaping of adaptive immunity [112]. TLRs are found on many hematopoietic cells including B, T, mast cells and dendritic cells (DCs) and expression is augmented by inflammatory mediators and danger signals. MSCs may be exposed to TLR ligands when administered to patients undergoing organ transplantation or indeed in any other inflammatory conditions. MSCs have been reported to express an array of TLRs and it is now clear that TLR signalling has an effect on MSC survival, differentiation, migration and immunosuppressive capacity. TLR3 and TLR4 stimulation prevented the suppressive effect of MSCs on T cell proliferation and this was dependent on the downregulation of the Notch ligand jagged 1 [113]. In contrast, Opitz et al demonstrated that TLR3 and TLR4 ligation enhanced MSC immunomodulation through the indirect induction of IDO1 [65]. A number of studies also report that TLR engagement in MSCs leads to changes in cytokine production [114-116] and therefore may allow further enhancement of immune suppression mediated by MSCs under certain conditions. Additionally, data demonstrate that ligation of TLR3 and TLR4, enhances MSC proliferation and migration in vitro $[116,117]$ and augments the efficacy of MSCs in vivo in a rat model of myocardial infarction [118]. In general it appears that TLR signalling does not significantly impact MSC immune suppression or trophic effects, but the consequences of TLR engagement and signalling in MSCs remain to be fully elucidated and therefore the field would benefit from further research in this area.

Although, monocytes/macrophages do not play a direct role in alloantigen presentation and therefore allorecognition; they actively infiltrate the allograft and proliferate in situ [119], contributing to the production of proinflammatory cytokines, reactive oxygen and nitrogen species [120]. Akin to the capacity of DCs to respond to their local microenvironment and become stimulatory or tolerogenic, monocytes and monocyte derived cells are also responsive to local cues. The best example of this is the generation of alternatively activated macrophages. Recent in vitro and in vivo data provide evidence that MSCs "educate" macrophages through cell-contact dependent cross talk leading to the generation of macrophages with an altered cytokine profile typically secreting IL-10 [121,122]. Another important role for macrophages is the participation in wound healing [123], the secretion of trophic factors by MSCs has been shown to recruit these cells in a mouse model of excisional wound healing [124]. Therefore it seems that while MSCs modulate macrophage cytokine profiles, they do not appear to interfere with intrinsic macrophage wound healing properties.

Unlike macrophages, neutrophils can mediate tissue damage directly through the production of cytotoxic granules and pro-inflammatory cytokines. It is recognised that neutrophils infiltrate organs within hours after transplantation in response to surgical trauma or ischemia/reperfusion. MSCs have been shown to indirectly modulate neutrophil migration in a mouse model of sepsis. Interestingly, MSC induced secretion of IL-10 by tissue resident macrophages which subsequently limited the extent of the neutrophil infiltrate [122]. Through in vitro experiments, the authors demonstrate that this process required complex interaction between MSCs and macrophages and involved LPS activation of TLR4 in MSCs, leading to MSC production of PGE-2 which was enhanced by TNF- $\alpha$ - TNF receptor 1 engagement on MSCs [122]. The capacity for MSCs to directly or indirectly attenuate the infiltration of neutrophils could potentially play an important part in MSC immune modulation of graft rejection and impact positively on the overall goal of the prevention of graft damage in the transplantation setting.

Natural killer (NK) cells can significantly impact the outcome of solid organ transplantation. NK cells are cytotoxic to major histocompatibility complex (MHC) class I mismatched allogeneic cells and target these cells for destruction through contact mediated release of perforin, granzyme and Fas ligand [125]. In addition, NK cells mediate their effector function through production of the proinflammatory cytokines IFN- $\gamma$ and TNF- $\alpha$. Early in vitro observations suggested that MSCs were not a target for lysis by freshly isolated NK cells and inhibited NK cell production of IFN- $\gamma[126,127]$. However, although more recent 
findings corroborate MSC suppressive effects on NK cell cytokine production, proliferation and effector function [128], there is some evidence demonstrating that MSCs can be lysed by activated NK cells [128-130]. Overall, the data discussed herein emphasise the complexity of interaction between MSCs and the innate immune system and highlights the potential for exploiting these effects in the setting of organ transplantation.

\section{Influence of MSCs on DCs}

DCs are the primary antigen presenting cells which play a critical role in the activation of the adaptive immune response; specifically the initiation of antigen specific $\mathrm{T}$ cell responses. Following organ transplantation, both donor and recipient derived DCs have the capacity to present alloantigen to recipient $\mathrm{T}$ cells through the direct and indirect pathways of allorecognition respectively [109,131].

As DCs play such an important role in allograft rejection; much attention has focused on the effect that MSCs have on DC development and function. Notably, a number of studies support the idea that MSCs inhibit or interfere with DC differentiation from precursor frequencies [132-135]. Importantly this effect is reversible and can be mediated by the MSC derived soluble factors IL-6 and PGE-2 [133]. MSCs may encounter DCs at different stages of development and under varying microenvironments and the specific conditions encountered will likely influence the effect that MSCs have on DCs. For example MSCs have differential effects on the generation of conventional DCs and plasmacytoid DCs [136].

Given the immune suppressive effects of MSCs, it seems likely that MSCs could orchestrate the induction of DCs with a regulatory or tolerogenic phenotype. To this end many studies have repeatedly shown that MSCs indeed induce a tolerogenic-like DC population through down modulation of MHC class II as well as the co-stimulatory molecules CD40, CD80 and CD86 [133,137-139]. This tolerogenic DC phenotype induced by MSCs was stable as restimulation with LPS did not reverse the effect. An outcome associated with MSC induction of tolerogenic DCs was a change in cytokine production involving a switch from pro-inflammatory cytokines (IL-12, TNF- $\alpha$ ) to the anti-inflammatory cytokine (IL-10) $[126,134,140]$. Notably, these MSC induced tolerogenic DCs display regulatory functions in their capacity to suppress the proliferation of rapidly expanding T cells [139], and to alter the ratio of $\mathrm{T}$ cell subsets and the frequency of regulatory $\mathrm{T}$ cells (Tregs) [137-141].

\section{Interactions between MSCs and the Adaptive Immune Response}

While $\mathrm{T}$ cell mediated immunity is central in allogeneic rejection mechanisms, humoral or antibody mediated immune responses are also involved [107-108]. Since the early reports outlining the capacity of MSCs to inhibit T cell proliferation in vitro, the field has progressed rapidly and we now have a greater understanding of how MSCs mediate their effects. A large body of data convincingly demonstrate that MSCs inhibit both alloantigen and mitogen driven $T$ cell proliferation $[64,142,143]$, but recent evidence suggests that MSCs have little effect on virally-driven proliferation [144].
Importantly, MSC capacity to modulate $\mathrm{T}$ cell responses is thought to be dependent on the inflammatory microenvironment present at the time of interaction between these two cell types $[66,145]$. Indeed a mechanistic study carried out by Ren and colleagues demonstrated a requirement for IFN- $\gamma$, TNF- $\alpha$ and/or IL- $1 \beta$ in the activation of MSC immune suppressive function [145].

Differentiation of naive helper $\mathrm{T}$ cells to specific subsets has also been shown to be altered in the presence of MSCs; skewing towards Tregs and preferential suppression of Th1, Th2 or Th17 depending on the system in question [122, 146,147]. Support for this scenario has been provided in in vivo models of transplantation and autoimmune diseases where MSCs accommodate the augmentation of $\mathrm{T}$ cell subsets in favour of a regulatory environment [141,147-149], and from preclinical models of MSC cell therapy where depletion of CD4+CD25+ FOXP3 + Treg ablated the protective effect of MSC [87].

Tregs certainly have the potential to induce tolerance in organ transplantation and it is well established that Tregs can control alloreactive $T$ cell responses [150-152]. Mechanistically, the induction of Tregs by MSCs is an important feature of MSC mediated immunosuppression particularly in the setting of transplantation; where the induction of tolerance to graft associated antigens is the paramount goal. To this end, MSC induced Tregs have been shown to be donor-specific in a mouse model of cardiac allograft rejection [148]. The mechanisms involved in MSC induction of Tregs have been investigated by a number of groups. While cell contact, PGE2 and TGF- $\beta$ have been identified as key mediators [153], MSC secretion of HLA-G in an -IL-10 and -cell contact dependent manner or in combination with LIF have also been identified to contribute to the expansion of Tregs in vitro in different systems $[154,155]$.

Although the majority of studies focus on the effects of MSCs on $\mathrm{CD}^{+} \mathrm{T}$ cells, a small number of reports have demonstrated that MSCs also inhibit $\mathrm{CD}^{+} \mathrm{T}$ cell proliferation $[127,156,157]$. However, there are inconsistencies with regard to data on the effect of MSCs on $\mathrm{CD} 8^{+} \mathrm{T}$ cell cytotoxicity $[127,157]$, which may be explained in part by an effect of MSCs on cell number, possibly through an increase in cell death. Importantly, it seems that MSCs are not targets for destruction by $\mathrm{CD}^{+} \mathrm{T}$ cells [127].

The other major component of the adaptive immune response is humoral or antibody mediated immunity implemented by B cells. Antibody mediated events have been associated with both acute and chronic rejection [107]. The effects of MSCs on B cell proliferation and function have been reported in vitro, with a small number of studies carried out using in vivo models. Data from the in vitro experiments involving co-culture of MSCs with purified populations of B cells under various stimulatory conditions, primarily demonstrate an inhibitory effect of MSCs on B cell proliferation, differentiation, Immunoglobulin (Ig) production and chemotaxis [158-164]. So far the mechanisms responsible for MSC modulation of $\mathrm{B}$ cell functions have been identified as alternatively cleaved CCL2 [162] or the combined effects of IFN$\gamma$, cell contact and PD1/PDL1 interaction [163]. In vivo models of pathogenic antibody production have demonstrated the 
capacity of MSCs to inhibit Ig production (including both T cell dependent and independent antibody responses) in vivo $[158,161,162]$. In contrast, data from others groups focusing on mouse models of SLE did not support these findings; with evidence of MSC failure to suppress auto-antibody production or increased auto-antibody titre and disease activity $[163,165]$. The discrepancy between these results may be due to differences in the systems examined (pathogenic versus autoimmune antibody production) or indeed the MSC populations used. Overall, the data highlight the capacity for MSC to modulate plasma cell function but also to stimulate these cells in specific circumstances and therefore emphasises the need for additional research using a number of different in vivo models in conjunction with a defined population of MSCs to provide consistency.

\section{Influence of the Combined Effects of MSC Reparative and Immune Suppressive Capacities}

As discussed above, organ transplantation is hampered not only by allogeneic rejection mechanisms but also ischemia/reperfusion or tissue injury associated with surgery. While current immunosuppressive regimens are targeted against the allogeneic rejection pathways; no specific measures are taken to combat the tissue injury common to organ transplantation. The immunosuppressive capabilities of MSCs combined with their inherent reparative functions, provides a possible therapeutic strategy to prevent graft rejection and enhance tissue repair. However, it seems likely that a combination therapy consisting of a brief period of immunosuppression followed by MSCs may facilitate a better outcome than MSCs or conventional immunosuppression alone.

Clearly the best studied clinical application of MSC therapy is in hematopoietic stem cell (HSC) transplantation, either for the enhancement of hematopoietic engraftment or for the treatment/prevention of GvHD. The capacity for MSCs to provide support for haematopoiesis combined with the inherent aptitude to encourage repair through secretion of trophic factors likely contributes to the increased levels and speed of engraftment seen in patients treated with MSCs [166,167]. As discussed above, one of the most interesting properties of MSCs is their capacity to modulate the immune response and data from clinical trials demonstrate a protective effect mediated by MSCs in patients with steroid resistant acute GvHD [74]. These published findings provide a platform for the use of MSCs in other clinical indications particularly that of organ transplantation. Trials utilising MSCs in solid organ transplantation have recently been initiated and over 100 trials using both the immune modulatory and or reparative effects of MSCs. The results from these trials will provide important insight into the applicability to MSCs in transplantation.

\section{CONFLICT OF INTEREST}

The authors confirm that this article content has no conflicts of interest.

\section{ACKNOWLEDGEMENTS}

K.J.W. is supported by the EU consortium grant Optistem. K.E. is supported by the European commission under a
Marie Curie Career Integration Grant and a HRB Translational Medicine Postdoctoral Fellowship. B.P.M. is supported by a Science Foundation Ireland Centre for Science and Engineering Technology (CSET) grant to the Regenerative Medicine Institute (REMEDI). The authors declare no potential conflict of interests.

\section{PATIENT CONSENT}

Declared none.

\section{REFERENCES}

[1] Young HE. Existence of reserve quiescent stem cells in adults, from amphibians to humans. Curr. Top Microbiol. Immunol., 2004, 280, 71-109.

[2] Young HE, Duplaa C, Romero-Ramos M, Chesselet MF, Vourc'h P, Yost MJ, Ericson K, Terracio L, Asahara T, Masuda H, TamuraNinomiya S, Detmer K, Bray RA, Steele TA, Hixson D, el-Kalay M, Tobin BW, Russ RD, Horst MN, Floyd JA, Henson NL, Hawkins KC, Groom J, Parikh A, Blake L, Bland LJ, Thompson AJ, Kirincich A, Moreau C, Hudson J, Bowyer FP, 3rd, Lin TJ, Black AC, Jr. Adult reserve stem cells and their potential for tissue engineering. Cell Biochem Biophys. 2004, 40(1), 1-80.

[3] Bearzi C, Leri A, Lo Monaco F, Rota M, Gonzalez A, Hosoda T, Pepe M, Qanud K, Ojaimi C, Bardelli S, D'Amario D, D'Alessandro DA, Michler RE, Dimmeler S, Zeiher AM, Urbanek K, Hintze TH, Kajstura J, Anversa P. Identification of a coronary vascular progenitor cell in the human heart. Proc Natl Acad Sci US A. 2009, 106(37), 15885-15890.

[4] Li C, Yang F, Sheppard A. Adult stem cells and mammalian epimorphic regeneration-insights from studying annual renewal of deer antlers. Curr Stem Cell Res Ther. 2009, 4(3), 237-251.

[5] Barry FP, Murphy JM. Mesenchymal stem cells, clinical applications and biological characterization. Int $J$ Biochem Cell Biol. 2004, 36(4), 568-584.

[6] Horwitz EM. Stem cell plasticity, the growing potential of cellular therapy. Arch Med Res. 2003, 34(6), 600-606.

[7] Caplan AI. Mesenchymal stem cells. J Orthop Res. 1991, 9(5), 641-650.

[8] Caplan AI. The mesengenic process. Clin Plast Surg. 1994, 21(3), 429-435.

[9] Friedenstein AJ, Chailakhyan RK, Latsinik NV, Panasyuk AF, Keiliss-Borok IV. Stromal cells responsible for transferring the microenvironment of the hemopoietic tissues. Cloning in vitro and retransplantation in vivo. Transplantation. 1974, 17(4), 331-340.

[10] Friedenstein AJP, Petrokova KV. Osteogenesis in transplants of bone marrow cells. Journal of Embyological Experimental Morphology. 1966, 16, 381-390.

[11] Jiang Y, Jahagirdar BN, Reinhardt RL, Schwartz RE, Keene CD, Ortiz-Gonzalez XR, Reyes M, Lenvik T, Lund T, Blackstad M, Du J, Aldrich S, Lisberg A, Low WC, Largaespada DA, Verfaillie CM. Pluripotency of mesenchymal stem cells derived from adult marrow. Nature. 2002, 418(6893), 41-49.

[12] Reyes M, Verfaillie CM. Characterization of multipotent adult progenitor cells, a subpopulation of mesenchymal stem cells. Ann N Y Acad Sci. 2001, 938, 231-233.

[13] D'Ippolito G, Diabira S, Howard GA, Menei P, Roos BA, Schiller PC. Marrow-isolated adult multilineage inducible (MIAMI) cells, a unique population of postnatal young and old human cells with extensive expansion and differentiation potential. J Cell Sci. 2004 117(Pt 14), 2971-2981.

[14] D'Ippolito G, Howard GA, Roos BA, Schiller PC. Sustained stromal stem cell self-renewal and osteoblastic differentiation during aging. Rejuvenation Res. 2006, 9(1), 10-19.

[15] Seandel M, James D, Shmelkov SV, Falciatori I, Kim J, Chavala S, Scherr DS, Zhang F, Torres R, Gale NW, Yancopoulos GD, Murphy A, Valenzuela DM, Hobbs RM, Pandolfi PP, Rafii S. Generation of functional multipotent adult stem cells from GPR125+ germline progenitors. Nature. 2007, 449(7160), 346-350.

[16] Crisan M, Yap S, Casteilla L, Chen CW, Corselli M, Park TS, Andriolo G, Sun B, Zheng B, Zhang L, Norotte C, Teng PN, Traas J, Schugar R, Deasy BM, Badylak S, Buhring HJ, Giacobino JP, Lazzari L, Huard J, Peault B. A perivascular origin for 
mesenchymal stem cells in multiple human organs. Cell Stem Cell. 2008, 3(3), 301-313.

[17] Gonzalez MA, Gonzalez-Rey E, Rico L, Buscher D, Delgado M. Adipose-derived mesenchymal stem cells alleviate experimental colitis by inhibiting inflammatory and autoimmune responses. Gastroenterology. 2009, 136(3), 978-989.

[18] Wang HS, Hung SC, Peng ST, Huang CC, Wei HM, Guo YJ, Fu YS, Lai MC, Chen CC. Mesenchymal stem cells in the Wharton's jelly of the human umbilical cord. Stem Cells. 2004, 22(7), 1330-1337.

[19] Young HE, Mancini ML, Wright RP, Smith JC, Black AC, Jr., Reagan CR, Lucas PA. Mesenchymal stem cells reside within the connective tissues of many organs. Dev Dyn. 1995, 202(2), 137-144.

[20] Dominici M, Le Blanc K, Mueller I, Slaper-Cortenbach I, Marini F, Krause D, Deans R, Keating A, Prockop D, Horwitz E. Minimal criteria for defining multipotent mesenchymal stromal cells. The International Society for Cellular Therapy position statement. Cytotherapy. 2006, 8(4), 315-317.

[21] Horwitz EM, Le Blanc K, Dominici M, Mueller I, SlaperCortenbach I, Marini FC, Deans RJ, Krause DS, Keating A. Clarification of the nomenclature for MSC, The International Society for Cellular Therapy position statement. Cytotherapy. 2005, 7(5), 393-395

[22] Digirolamo CM, Stokes D, Colter D, Phinney DG, Class R, Prockop DJ. Propagation and senescence of human marrow stromal cells in culture, a simple colony-forming assay identifies samples with the greatest potential to propagate and differentiate. $\mathrm{Br} J$ Haematol. 1999, 107(2), 275-281.

[23] Muraglia A, Cancedda R, Quarto R. Clonal mesenchymal progenitors from human bone marrow differentiate in vitro according to a hierarchical model. J Cell Sci. 2000, 113 ( Pt 7), 1161-1166.

[24] Haniffa MA, Collin MP, Buckley CD, Dazzi F. Mesenchymal stem cells, the fibroblasts' new clothes? Haematologica. 2009, 94(2), 258-263.

[25] Koga H, Muneta T, Nagase T, Nimura A, Ju YJ, Mochizuki T, Sekiya I. Comparison of mesenchymal tissues-derived stem cells for in vivo chondrogenesis, suitable conditions for cell therapy of cartilage defects in rabbit. Cell Tissue Res. 2008, 333(2), 207-215.

[26] Huang GT, Gronthos S, Shi S. Mesenchymal stem cells derived from dental tissues vs. those from other sources, their biology and role in regenerative medicine. J Dent Res. 2009, 88(9), 792-806.

[27] Chang C, Niu D, Zhou H, Li F, Gong F. Mesenchymal stem cells contribute to insulin-producing cells upon microenvironmental manipulation in vitro. Transplant Proc. 2007, 39(10), 3363-3368.

[28] Chien CC, Yen BL, Lee FK, Lai TH, Chen YC, Chan SH, Huang HI. In vitro differentiation of human placenta-derived multipotent cells into hepatocyte-like cells. Stem Cells. 2006, 24(7), 1759-1768. Fukunaga A, Uchida K, Hara K, Kuroshima Y, Kawase T. Differentiation and angiogenesis of central nervous system stem cells implanted with mesenchyme into ischemic rat brain. Cell Transplant. 1999, 8(4), 435-441.

[30] Herzog EL, Chai L, Krause DS. Plasticity of marrow-derived stem cells. Blood. 2003, 102(10), 3483-3493.

[31] Li Y, Zhang R, Qiao H, Zhang H, Wang Y, Yuan H, Liu Q, Liu D, Chen L, Pei X. Generation of insulin-producing cells from PDX-1 gene-modified human mesenchymal stem cells. J Cell Physiol. 2007, 211(1), 36-44

[32] Munoz-Elias G, Woodbury D, Black IB. Marrow stromal cells, mitosis, and neuronal differentiation, stem cell and precursor functions. Stem Cells. 2003, 21(4), 437-448.

[33] Pittenger MF, Mackay AM, Beck SC, Jaiswal RK, Douglas R, Mosca JD, Moorman MA, Simonetti DW, Craig S, Marshak DR. Multilineage potential of adult human mesenchymal stem cells. Science. 1999, 284(5411), 143-147.

[34] Sasaki M, Abe R, Fujita Y, Ando S, Inokuma D, Shimizu H. Mesenchymal stem cells are recruited into wounded skin and contribute to wound repair by transdifferentiation into multiple skin cell type. J Immunol. 2008, 180(4), 2581-2587.

[35] Woodbury D, Reynolds K, Black IB. Adult bone marrow stromal stem cells express germline, ectodermal, endodermal, and mesodermal genes prior to neurogenesis. J Neurosci Res. 2002, 69(6), 908-917.

[36] Barry FP. Biology and clinical applications of mesenchymal stem cells. Birth Defects Res C Embryo Today. 2003, 69(3), 250-256.

[37] Jackson KA, Majka SM, Wang H, Pocius J, Hartley CJ, Majesky MW, Entman ML, Michael LH, Hirschi KK, Goodell MA.

Regeneration of ischemic cardiac muscle and vascular endothelium by adult stem cells. $J$ Clin Invest. 2001, 107(11), 1395-1402.

[48] Kasten P, Vogel J, Luginbuhl R, Niemeyer P, Tonak M, Lorenz H, Helbig L, Weiss S, Fellenberg J, Leo A, Simank HG, Richter W. Ectopic bone formation associated with mesenchymal stem cells in a resorbable calcium deficient hydroxyapatite carrier. Biomaterials. 2005, 26(29), 5879-5889.

[49] Ko EK, Jeong SI, Rim NG, Lee YM, Shin H, Lee BK. In vitro osteogenic differentiation of human mesenchymal stem cells and in vivo bone formation in composite nanofiber meshes. Tissue Eng Part A. 2008, 14(12), 2105-2119.

[50] Morigi M, Benigni A, Remuzzi G, Imberti B. The regenerative potential of stem cells in acute renal failure. Cell Transplant. 2006, 15 Suppl 1, S111-117.

[51] Morigi M, Imberti B, Zoja C, Corna D, Tomasoni S, Abbate M, Rottoli D, Angioletti S, Benigni A, Perico N, Alison M, Remuzzi G. Mesenchymal stem cells are renotropic, helping to repair the kidney and improve function in acute renal failure. $\mathrm{J} \mathrm{Am} \mathrm{Soc}$ Nephrol. 2004, 15(7), 1794-1804.

[52] Kode JA, Mukherjee S, Joglekar MV, Hardikar AA. Mesenchymal stem cells, immunobiology and role in immunomodulation and tissue regeneration. Cytotherapy. 2009, 11(4), 377-391.

[53] Lange C, Togel F, Ittrich H, Clayton F, Nolte-Ernsting C, Zander AR, Westenfelder C. Administered mesenchymal stem cells enhance recovery from ischemia/reperfusion-induced acute renal failure in rats. Kidney Int. 2005, 68(4), 1613-1617.

[54] Togel F, Hu Z, Weiss $\mathrm{K}$, Isaac J, Lange C, Westenfelder C. Administered mesenchymal stem cells protect against ischemic acute renal failure through differentiation-independent mechanisms. Am J Physiol Renal Physiol. 2005, 289(1), F31-42.

[55] Togel F, Weiss K, Yang Y, Hu Z, Zhang P, Westenfelder C. Vasculotropic, paracrine actions of infused mesenchymal stem cells 
are important to the recovery from acute kidney injury. Am $J$ Physiol Renal Physiol. 2007, 292(5), F1626-1635.

[56] Togel F, Westenfelder C. Adult bone marrow-derived stem cells for organ regeneration and repair. Dev Dyn. 2007, 236(12), 33213331.

[57] Togel F, Yang $\mathrm{Y}$, Zhang $\mathrm{P}$, $\mathrm{Hu} \mathrm{Z}$, Westenfelder $\mathrm{C}$. Bioluminescence imaging to monitor the in vivo distribution of administered mesenchymal stem cells in acute kidney injury. Am J Physiol Renal Physiol. 2008, 295(1), F315-321.

[58] Caplan AI. Why are MSCs therapeutic? New data, new insight. $J$ Pathol. 2009, 217(2), 318-324.

[59] Caplan AI, Dennis JE. Mesenchymal stem cells as trophic mediators. J Cell Biochem. 2006, 98(5), 1076-1084.

[60] Dore-Duffy P. Pericytes, pluripotent cells of the blood brain barrier. Curr Pharm Des. 2008, 14(16), 1581-1593.

[61] Bianco P, Robey PG, Saggio I, Riminucci M. "Mesenchymal" stem cells in human bone marrow (skeletal stem cells), a critical discussion of their nature, identity, and significance in incurable skeletal disease. Hum Gene Ther. 2010, 21(9), 1057-1066.

[62] Charbord P, Livne E, Gross G, Haupl T, Neves NM, Marie P, Bianco P, Jorgensen C. Human Bone Marrow Mesenchymal Stem Cells, A Systematic Reappraisal Via the Genostem Experience. Stem Cell Rev. 2010.

[63] Lee MW, Choi J, Yang MS, Moon YJ, Park JS, Kim HC, Kim YJ. Mesenchymal stem cells from cryopreserved human umbilical cord blood. Biochem Biophys Res Commun. 2004, 320(1), 273-278.

[64] English K, Barry FP, Field-Corbett CP, Mahon BP. IFN-gamma and TNF-alpha differentially regulate immunomodulation by murine mesenchymal stem cells. Immunol Lett. 2007, 110(2), 91-100.

[65] Opitz CA, Litzenburger UM, Lutz C, Lanz TV, Tritschler I, Koppel A, Tolosa E, Hoberg M, Anderl J, Aicher WK, Weller M, Wick W, Platten M. Toll-like receptor engagement enhances the immunosuppressive properties of human bone marrow-derived mesenchymal stem cells by inducing indoleamine-2,3-dioxygenase1 via interferon-beta and protein kinase R. Stem Cells. 2009, 27(4), 909-919.

[66] Polchert D, Sobinsky J, Douglas G, Kidd M, Moadsiri A, Reina E, Genrich K, Mehrotra S, Setty S, Smith B, Bartholomew A. IFNgamma activation of mesenchymal stem cells for treatment and prevention of graft versus host disease. Eur J Immunol. 2008, 38(6), 1745-1755.

[67] Prasanna SJ, Gopalakrishnan D, Shankar SR, Vasandan AB. Proinflammatory cytokines, IFNgamma and TNFalpha, influence immune properties of human bone marrow and Wharton jelly mesenchymal stem cells differentially. PLoS One. 2010, 5(2), e9016.

[68] Ryan JM, Barry F, Murphy JM, Mahon BP. Interferon-gamma does not break, but promotes the immunosuppressive capacity of adult human mesenchymal stem cells. Clin Exp Immunol. 2007, 149(2), 353-363.

[69] Valencic E, Piscianz E, Andolina M, Ventura A, Tommasini A. The immunosuppressive effect of Wharton's jelly stromal cells depends on the timing of their licensing and on lymphocyte activation. Cytotherapy. 2010, 12(2), 154-160.

[70] Fang B, Shi M, Liao L, Yang S, Liu Y, Zhao RC. Systemic infusion of FLK1 $(+)$ mesenchymal stem cells ameliorate carbon tetrachloride-induced liver fibrosis in mice. Transplantation. 2004, 78(1), 83-88.

[71] Ninichuk V, Gross O, Segerer S, Hoffmann R, Radomska E, Buchstaller A, Huss R, Akis N, Schlondorff D, Anders HJ. Multipotent mesenchymal stem cells reduce interstitial fibrosis but do not delay progression of chronic kidney disease in collagen4A3deficient mice. Kidney Int. 2006, 70(1), 121-129.

[72] Neuss S, Becher E, Woltje M, Tietze L, Jahnen-Dechent W. Functional expression of HGF and HGF receptor/c-met in adult human mesenchymal stem cells suggests a role in cell mobilization, tissue repair, and wound healing. Stem Cells. 2004, 22(3), 405-414.

[73] Lee $\mathrm{CH}$, Shah B, Moioli EK, Mao JJ. CTGF directs fibroblast differentiation from human mesenchymal stem/stromal cells and defines connective tissue healing in a rodent injury model. $J$ Clin Invest. 2010, 120(9), 3340-3349.

[74] Le Blanc K, Frassoni F, Ball L, Locatelli F, Roelofs H, Lewis I, Lanino E, Sundberg B, Bernardo ME, Remberger M, Dini G, Egeler RM, Bacigalupo A, Fibbe W, Ringden O. Mesenchymal stem cells for treatment of steroid-resistant, severe, acute graft- versus-host disease, a phase II study. Lancet. 2008, 371(9624), 1579-1586.

[75] Bass AS, Cartwright ME, Mahon C, Morrison R, Snyder R, McNamara P, Bradley P, Zhou YY, Hunter J. Exploratory drug safety, a discovery strategy to reduce attrition in development. $J$ Pharmacol Toxicol Methods. 2009, 60(1), 69-78.

[76] McNeish J. Embryonic stem cells in drug discovery. Nat Rev Drug Discov. 2004, 3(1), 70-80.

[77] Webb S. iPS cell technology gains momentum in drug discovery. Nat Rev Drug Discov. 2009, 8(4), 263-264.

[78] Winkler J, Sotiriadou I, Chen S, Hescheler J, Sachinidis A. The potential of embryonic stem cells combined with -omics technologies as model systems for toxicology. Curr Med Chem. 2009, 16(36), 4814-4827.

[79] Ding S, Schultz PG. A role for chemistry in stem cell biology. Nat Biotechnol. 2004, 22(7), 833-840.

[80] Ding S, Schultz PG. Small molecules and future regenerative medicine. Curr Top Med Chem. 2005, 5(4), 383-395.

[81] Kim NR, Kang SK, Ahn HH, Kwon SW, Park WS, Kim KS, Kim SS, Jung HJ, Choi SU, Ahn JH, Kim KR. Discovery of a new and efficient small molecule for neuronal differentiation from mesenchymal stem cell. J Med Chem. 2009, 52(24), 7931-7933.

[82] Mai A, Valente S, Meade S, Carafa V, Tardugno M, Nebbioso A, Galmozzi A, Mitro N, De Fabiani E, Altucci L, Kazantsev A. Study of 1,4-dihydropyridine structural scaffold, discovery of novel sirtuin activators and inhibitors. J Med Chem. 2009, 52(17), 5496-5504.

[83] Sakai N, Terami H, Suzuki S, Haga M, Nomoto K, Tsuchida N, Morohashi K, Saito N, Asada M, Hashimoto M, Harada D, Asahara H, Ishikawa T, Shimada F, Sakurada K. Identification of NR5A1 (SF-1/AD4BP) gene expression modulators by large-scale gain and loss of function studies. J Endocrinol. 2008, 198(3), 489-497.

[84] Flanagan JM, Funes JM, Henderson S, Wild L, Carey N, Boshoff C. Genomics screen in transformed stem cells reveals RNASEH2A, PPAP2C, and ADARB1 as putative anticancer drug targets. $\mathrm{Mol}$ Cancer Ther. 2009, 8(1), 249-260.

[85] Patel SA, Heinrich AC, Reddy BY, Srinivas B, Heidaran N, Rameshwar P. Breast cancer biology, the multifaceted roles of mesenchymal stem cells. J Oncol. 2008, 2008, 425895.

[86] Bushway PJ, Mercola M. High-throughput screening for modulators of stem cell differentiation. Methods Enzymol. 2006, 414, 300-316.

[87] Kavanagh H, Mahon BP. Allogeneic mesenchymal stem cells prevent allergic airway inflammation by inducing murine regulatory T cells. Allergy. $\mathbf{2 0 1 0}$.

[88] Erfle H, Neumann B, Rogers P, Bulkescher J, Ellenberg J, Pepperkok R. Work flow for multiplexing siRNA assays by solidphase reverse transfection in multiwell plates. $J$ Biomol Screen. 2008, 13(7), 575-580.

[89] Neumann B, Held M, Liebel U, Erfle H, Rogers P, Pepperkok R, Ellenberg J. High-throughput RNAi screening by time-lapse imaging of live human cells. Nat Methods. 2006, 3(5), 385-390.

[90] Walter T, Held M, Neumann B, Heriche JK, Conrad C, Pepperkok $\mathrm{R}$, Ellenberg J. Automatic identification and clustering of chromosome phenotypes in a genome wide RNAi screen by timelapse imaging. J Struct Biol. 2010, 170(1), 1-9.

[91] Huang AH, Motlekar NA, Stein A, Diamond SL, Shore EM, Mauck RL. High-throughput screening for modulators of mesenchymal stem cell chondrogenesis. Ann Biomed Eng. 2008, 36(11), 1909-1921.

[92] Kawakami Y, Tsuda M, Takahashi S, Taniguchi N, Esteban CR, Zemmyo M, Furumatsu T, Lotz M, Belmonte JC, Asahara H. Transcriptional coactivator PGC-1alpha regulates chondrogenesis via association with Sox9. Proc Natl Acad Sci U S A. 2005, 102(7), 2414-2419.

[93] Takada I, Kouzmenko AP, Kato S. Wnt and PPARgamma signaling in osteoblastogenesis and adipogenesis. Nat Rev Rheumatol. 2009, 5(8), 442-447.

[94] Takada I, Kouzmenko AP, Kato S. Molecular switching of osteoblastogenesis versus adipogenesis, implications for targeted therapies. Expert Opin Ther Targets. 2009, 13(5), 593-603.

[95] Dicker A, Kaaman M, van Harmelen V, Astrom G, Blanc KL, Ryden M. Differential function of the alpha2A-adrenoceptor and Phosphodiesterase-3B in human adipocytes of different origin. Int $J$ Obes (Lond). 2005, 29(12), 1413-1421.

[96] McNeish JD. Stem cells as screening tools in drug discovery. Curr Opin Pharmacol. 2007, 7(5), 515-520. 
[97] Musina RA, Bekchanova ES, Belyavskii AV, Sukhikh GT. Differentiation potential of mesenchymal stem cells of different origin. Bull Exp Biol Med. 2006, 141(1), 147-151.

[98] Qian SW, Li X, Zhang YY, Huang HY, Liu Y, Sun X, Tang QQ. Characterization of adipocyte differentiation from human mesenchymal stem cells in bone marrow. BMC Dev Biol. 2010, 10, 47.

[99] Erfle H, Neumann B, Liebel U, Rogers P, Held M, Walter T, Ellenberg J, Pepperkok R. Reverse transfection on cell arrays for high content screening microscopy. Nat Protoc. 2007, 2(2), 392-399.

[100] Neumann B, Walter T, Heriche JK, Bulkescher J, Erfle H, Conrad C, Rogers P, Poser I, Held M, Liebel U, Cetin C, Sieckmann F, Pau G, Kabbe R, Wunsche A, Satagopam V, Schmitz MH, Chapuis C, Gerlich DW, Schneider R, Eils R, Huber W, Peters JM, Hyman AA, Durbin R, Pepperkok R, Ellenberg J. Phenotypic profiling of the human genome by time-lapse microscopy reveals cell division genes. Nature. 2010, 464(7289), 721-727.

[101] Freeley M, Bakos G, Davies A, Kelleher D, Long A, Dunican DJ. A high-content analysis toolbox permits dissection of diverse signaling pathways for $\mathrm{T}$ lymphocyte polarization. $J$ Biomol Screen. 2010, 15(5), 541-555.

[102] Kozak K, Bakos G, Hoff A, Bennett E, Dunican D, Davies A, Kelleher D, Long A, Csucs G. Workflow-based software environment for large-scale biological experiments. J Biomol Screen. 2010, 15(7), 892-899.

[103] Verma NK, Davies AM, Long A, Kelleher D, Volkov Y. STAT3 knockdown by siRNA induces apoptosis in human cutaneous T-cell lymphoma line Hut78 via downregulation of Bcl-xL. Cell Mol Biol Lett. 2010, 15(2), 342-355.

[104] English K, French A, Wood KJ. Mesenchymal stromal cells, facilitators of successful transplantation? Cell Stem Cell. 2010, 7(4), 431-442.

[105] Lopez MM, Valenzuela JE, Alvarez FC, Lopez-Alvarez MR, Cecilia GS, Paricio PP. Long-term problems related to immunosuppression. Transpl Immunol. 2006, 17(1), 31-35.

[106] Ding Y, Bushell A, Wood KJ. Mesenchymal stem-cell immunosuppressive capabilities, therapeutic implications in islet transplantation. Transplantation. 2010, 89(3), 270-273.

[107] Colvin RB, Smith RN. Antibody-mediated organ-allograft rejection. Nat Rev Immunol. 2005, 5(10), 807-817.

[108] Hall BM, Dorsch S, Roser B. The cellular basis of allograft rejection in vivo. I. The cellular requirements for first-set rejection of heart grafts. $J$ Exp Med. 1978, 148(4), 878-889.

[109] LaRosa DF, Rahman AH, Turka LA. The innate immune system in allograft rejection and tolerance. J Immunol. 2007, 178(12), 7503-7509.

[110] Tu Z, Li Q, Bu H, Lin F. Mesenchymal stem cells inhibit complement activation by secreting factor H. Stem Cells Dev. 2010, 19(11), 1803-1809.

[111] Schraufstatter IU, Discipio RG, Zhao M, Khaldoyanidi SK. C3a and $\mathrm{C} 5 \mathrm{a}$ are chemotactic factors for human mesenchymal stem cells, which cause prolonged ERK1/2 phosphorylation. J Immunol. 2009, 182(6), 3827-3836.

[112] Schnare M, Barton GM, Holt AC, Takeda K, Akira S, Medzhitov R. Toll-like receptors control activation of adaptive immune responses. Nat Immunol. 2001, 2(10), 947-950.

[113] Liotta F, Angeli R, Cosmi L, Fili L, Manuelli C, Frosali F, Mazzinghi B, Maggi L, Pasini A, Lisi V, Santarlasci V, Consoloni L, Angelotti ML, Romagnani P, Parronchi P, Krampera M, Maggi E, Romagnani S, Annunziato F. Toll-like receptors 3 and 4 are expressed by human bone marrow-derived mesenchymal stem cells and can inhibit their T-cell modulatory activity by impairing Notch signaling. Stem Cells. 2008, 26(1), 279-289.

[114] Hwa Cho H, Bae YC, Jung JS. Role of toll-like receptors on human adipose-derived stromal cells. Stem Cells. 2006, 24(12), 2744-2752.

[115] Lombardo E, DelaRosa O, Mancheno-Corvo P, Menta R, Ramirez C, Buscher D. Toll-like receptor-mediated signaling in human adipose-derived stem cells, implications for immunogenicity and immunosuppressive potential. Tissue Eng Part A. 2009, 15(7), 1579-1589.

[116] Tomchuck SL, Zwezdaryk KJ, Coffelt SB, Waterman RS, Danka ES, Scandurro AB. Toll-like receptors on human mesenchymal stem cells drive their migration and immunomodulating responses. Stem Cells. 2008, 26(1), 99-107.

[117] Wang ZJ, Zhang FM, Wang LS, Yao YW, Zhao Q, Gao X. Lipopolysaccharides can protect mesenchymal stem cells (MSCs) from oxidative stress-induced apoptosis and enhance proliferation of MSCs via Toll-like receptor(TLR)-4 and PI3K/Akt. Cell Biol Int. 2009, 33(6), 665-674.

[118] Yao Y, Zhang F, Wang L, Zhang G, Wang Z, Chen J, Gao X. Lipopolysaccharide preconditioning enhances the efficacy of mesenchymal stem cells transplantation in a rat model of acute myocardial infarction. J Biomed Sci. 2009, 16, 74.

[119] Grau V, Herbst B, Steiniger B. Dynamics of monocytes/ macrophages and $\mathrm{T}$ lymphocytes in acutely rejecting rat renal allografts. Cell Tissue Res. 1998, 291(1), 117-126.

[120] Wyburn KR, Jose MD, Wu H, Atkins RC, Chadban SJ. The role of macrophages in allograft rejection. Transplantation. 2005, 80(12), 1641-1647.

[121] Kim J, Hematti P. Mesenchymal stem cell-educated macrophages, a novel type of alternatively activated macrophages. Exp Hematol. 2009, 37(12), 1445-1453.

[122] Nemeth K, Leelahavanichkul A, Yuen PS, Mayer B, Parmelee A, Doi K, Robey PG, Leelahavanichkul K, Koller BH, Brown JM, Hu $\mathrm{X}$, Jelinek I, Star RA, Mezey E. Bone marrow stromal cells attenuate sepsis via prostaglandin $\mathrm{E}(2)$-dependent reprogramming of host macrophages to increase their interleukin-10 production. Nat Med. 2009, 15(1), 42-49.

[123] Mirza R, DiPietro LA, Koh TJ. Selective and specific macrophage ablation is detrimental to wound healing in mice. Am J Pathol. 2009, 175(6), 2454-2462.

[124] Chen L, Tredget EE, Wu PY, Wu Y. Paracrine factors of mesenchymal stem cells recruit macrophages and endothelial lineage cells and enhance wound healing. PLoS One. 2008, 3(4), e1886.

[125] Taylor MA, Ward B, Schatzle JD, Bennett M. Perforin- and Fasdependent mechanisms of natural killer cell-mediated rejection of incompatible bone marrow cell grafts. Eur J Immunol. 2002, 32(3), 793-799.

[126] Aggarwal S, Pittenger MF. Human mesenchymal stem cells modulate allogeneic immune cell responses. Blood. 2005, 105(4), 1815-1822.

[127] Rasmusson I, Ringden O, Sundberg B, Le Blanc K. Mesenchymal stem cells inhibit the formation of cytotoxic T lymphocytes, but not activated cytotoxic $\mathrm{T}$ lymphocytes or natural killer cells. Transplantation. 2003, 76(8), 1208-1213.

[128] Spaggiari GM, Capobianco A, Abdelrazik H, Becchetti F, Mingari MC, Moretta L. Mesenchymal stem cells inhibit natural killer-cell proliferation, cytotoxicity, and cytokine production, role of indoleamine 2,3-dioxygenase and prostaglandin E2. Blood. 2008, 111(3), 1327-1333.

[129] Sotiropoulou PA, Perez SA, Gritzapis AD, Baxevanis CN, Papamichail M. Interactions between human mesenchymal stem cells and natural killer cells. Stem Cells. 2006, 24(1), 74-85.

[130] Spaggiari GM, Capobianco A, Becchetti S, Mingari MC, Moretta L. Mesenchymal stem cell-natural killer cell interactions, evidence that activated NK cells are capable of killing MSCs, whereas MSCs can inhibit IL-2-induced NK-cell proliferation. Blood. 2006 , 107(4), 1484-1490.

[131] Shoskes DA, Wood KJ. Indirect presentation of MHC antigens in transplantation. Immunol Today. 1994, 15(1), 32-38.

[132] Beyth S, Borovsky Z, Mevorach D, Liebergall M, Gazit Z, Aslan H, Galun E, Rachmilewitz J. Human mesenchymal stem cells alter antigen-presenting cell maturation and induce T-cell unresponsiveness. Blood. 2005, 105(5), 2214-2219.

[133] Djouad F, Charbonnier LM, Bouffi C, Louis-Plence P, Bony C, Apparailly F, Cantos C, Jorgensen C, Noel D. Mesenchymal stem cells inhibit the differentiation of dendritic cells through an interleukin-6dependent mechanism. Stem Cells. 2007, 25(8), 2025-2032.

[134] Jiang XX, Zhang Y, Liu B, Zhang SX, Wu Y, Yu XD, Mao N. Human mesenchymal stem cells inhibit differentiation and function of monocyte-derived dendritic cells. Blood. 2005, 105(10), 4120-4126.

[135] Nauta AJ, Kruisselbrink AB, Lurvink E, Willemze R, Fibbe WE. Mesenchymal stem cells inhibit generation and function of both CD34+-derived and monocyte-derived dendritic cells. J Immunol. 2006, 177(4), 2080-2087.

[136] Chen L, Zhang W, Yue H, Han Q, Chen B, Shi M, Li J, Li B, You S, Shi Y, Zhao RC. Effects of human mesenchymal stem cells on the differentiation of dendritic cells from CD34+ cells. Stem Cells Dev. 2007, 16(5), 719-731.

[137] Li YP, Paczesny S, Lauret E, Poirault S, Bordigoni P, Mekhloufi F, Hequet O, Bertrand Y, Ou-Yang JP, Stoltz JF, Miossec P, Eljaafari A. Human mesenchymal stem cells license adult CD34+ hemopoietic progenitor cells to differentiate into regulatory 
dendritic cells through activation of the Notch pathway. J Immunol. 2008, 180(3), 1598-1608.

[138] Wehner R, Wehrum D, Bornhauser M, Zhao S, Schakel K, Bachmann MP, Platzbecker U, Ehninger G, Rieber EP, Schmitz M. Mesenchymal stem cells efficiently inhibit the proinflammatory properties of 6-sulfo LacNAc dendritic cells. Haematologica. 2009, 94(8), 1151-1156.

[139] Zhang B, Liu R, Shi D, Liu X, Chen Y, Dou X, Zhu X, Lu C, Liang W, Liao L, Zenke M, Zhao RC. Mesenchymal stem cells induce mature dendritic cells into a novel Jagged-2-dependent regulatory dendritic cell population. Blood. 2009, 113(1), 46-57.

[140] Zhang W, Ge W, Li C, You S, Liao L, Han Q, Deng W, Zhao RC. Effects of mesenchymal stem cells on differentiation, maturation, and function of human monocyte-derived dendritic cells. Stem Cells Dev. 2004, 13(3), 263-271.

[141] Ge W, Jiang J, Baroja ML, Arp J, Zassoko R, Liu W, Bartholomew A, Garcia B, Wang H. Infusion of mesenchymal stem cells and rapamycin synergize to attenuate alloimmune responses and promote cardiac allograft tolerance. Am J Transplant. 2009, 9(8), 1760-1772.

[142] Di Nicola M, Carlo-Stella C, Magni M, Milanesi M, Longoni PD, Matteucci P, Grisanti S, Gianni AM. Human bone marrow stromal cells suppress T-lymphocyte proliferation induced by cellular or nonspecific mitogenic stimuli. Blood. 2002, 99(10), 3838-3843.

[143] Ding Y, Xu D, Feng G, Bushell A, Muschel RJ, Wood KJ. Mesenchymal stem cells prevent the rejection of fully allogenic islet grafts by the immunosuppressive activity of matrix metalloproteinase-2 and -9. Diabetes. 2009, 58(8), 1797-1806.

[144] Karlsson H, Samarasinghe S, Ball LM, Sundberg B, Lankester AC, Dazzi F, Uzunel M, Rao K, Veys P, Le Blanc K, Ringden O, Amrolia PJ. Mesenchymal stem cells exert differential effects on alloantigen and virus-specific T-cell responses. Blood. 2008, 112(3), 532-541.

[145] Ren G, Zhang L, Zhao X, Xu G, Zhang Y, Roberts AI, Zhao RC, Shi Y. Mesenchymal stem cell-mediated immunosuppression occurs via concerted action of chemokines and nitric oxide. Cell Stem Cell. 2008, 2(2), 141-150.

[146] Ghannam S, Pene J, Torcy-Moquet G, Jorgensen C, Yssel H. Mesenchymal stem cells inhibit human Th17 cell differentiation and function and induce a T regulatory cell phenotype. J Immunol. 2010, 185(1), 302-312.

[147] Rafei M, Campeau PM, Aguilar-Mahecha A, Buchanan M, Williams P, Birman E, Yuan S, Young YK, Boivin MN, Forner K, Basik M, Galipeau J. Mesenchymal stromal cells ameliorate experimental autoimmune encephalomyelitis by inhibiting CD4 Th17 T cells in a CC chemokine ligand 2-dependent manner. $J$ Immunol. 2009, 182(10), 5994-6002.

[148] Casiraghi F, Azzollini N, Cassis P, Imberti B, Morigi M, Cugini D, Cavinato RA, Todeschini M, Solini S, Sonzogni A, Perico N, Remuzzi G, Noris M. Pretransplant infusion of mesenchymal stem cells prolongs the survival of a semiallogeneic heart transplant through the generation of regulatory $\mathrm{T}$ cells. $J$ Immunol. 2008, 181(6), 3933-3946.

[149] Kong QF, Sun B, Bai SS, Zhai DX, Wang GY, Liu YM, Zhang SJ, Li R, Zhao W, Sun YY, Li N, Wang Q, Peng HS, Jin LH, Li HL. Administration of bone marrow stromal cells ameliorates experimental autoimmune myasthenia gravis by altering the balance of Th1/Th2/Th17/Treg cell subsets through the secretion of TGF-beta. J Neuroimmunol. 2009, 207(1-2), 83-91.

[150] Long E, Wood KJ. Regulatory T cells in transplantation, transferring mouse studies to the clinic. Transplantation. 2009, 88(9), 1050-1056.

[151] Nadig SN, Wieckiewicz J, Wu DC, Warnecke G, Zhang W, Luo S, Schiopu A, Taggart DP, Wood KJ. In vivo prevention of transplant arteriosclerosis by ex vivo-expanded human regulatory T cells. $\mathrm{Nat}$ Med. 2010, 16(7), 809-813.

[152] Wood KJ, Sakaguchi S. Regulatory $\mathrm{T}$ cells in transplantation tolerance. Nat Rev Immunol. 2003, 3(3), 199-210.

[153] English K, Ryan JM, Tobin L, Murphy MJ, Barry FP, Mahon BP. Cell contact, prostaglandin $\mathrm{E}(2)$ and transforming growth factor beta 1 play non-redundant roles in human mesenchymal stem cell induction of CD4+CD25(High) forkhead box P3+ regulatory $\mathrm{T}$ cells. Clin Exp Immunol. 2009, 156(1), 149-160.

[154] Nasef A, Mazurier C, Bouchet S, Francois S, Chapel A, Thierry D, Gorin NC, Fouillard L. Leukemia inhibitory factor, Role in human mesenchymal stem cells mediated immunosuppression. Cell Immunol. 2008, 253(1-2), 16-22.

[155] Selmani Z, Naji A, Zidi I, Favier B, Gaiffe E, Obert L, Borg C Saas P, Tiberghien P, Rouas-Freiss N, Carosella ED, Deschaseaux F. Human leukocyte antigen-G5 secretion by human mesenchymal stem cells is required to suppress T lymphocyte and natural killer function and to induce CD4+CD25highFOXP3+ regulatory T cells. Stem Cells. 2008, 26(1), 212-222.

[156] Maccario R, Podesta M, Moretta A, Cometa A, Comoli P, Montagna D, Daudt L, Ibatici A, Piaggio G, Pozzi S, Frassoni F, Locatelli F. Interaction of human mesenchymal stem cells with cells involved in alloantigen-specific immune response favors the differentiation of CD4+ T-cell subsets expressing a regulatory/ suppressive phenotype. Haematologica. 2005, 90(4), 516-525.

[157] Ramasamy R, Tong CK, Seow HF, Vidyadaran S, Dazzi F. The immunosuppressive effects of human bone marrow-derived mesenchymal stem cells target $\mathrm{T}$ cell proliferation but not its effector function. Cell Immunol. 2008, 251(2), 131-136.

[158] Asari S, Itakura S, Ferreri K, Liu CP, Kuroda Y, Kandeel F, Mullen Y. Mesenchymal stem cells suppress B-cell terminal differentiation. Exp Hematol. 2009, 37(5), 604-615.

[159] Comoli P, Ginevri F, Maccario R, Avanzini MA, Marconi M, Groff A, Cometa A, Cioni M, Porretti L, Barberi W, Frassoni F, Locatelli F. Human mesenchymal stem cells inhibit antibody production induced in vitro by allostimulation. Nephrol Dial Transplant. 2008, 23(4), 1196-1202.

[160] Corcione A, Benvenuto F, Ferretti E, Giunti D, Cappiello V, Cazzanti F, Risso M, Gualandi F, Mancardi GL, Pistoia V, Uccelli A. Human mesenchymal stem cells modulate B-cell functions. Blood. 2006, 107(1), 367-372.

[161] Gerdoni E, Gallo B, Casazza S, Musio S, Bonanni I, Pedemonte E, Mantegazza R, Frassoni F, Mancardi G, Pedotti R, Uccelli A. Mesenchymal stem cells effectively modulate pathogenic immune response in experimental autoimmune encephalomyelitis. Ann Neurol. 2007, 61(3), 219-227.

[162] Rafei M, Hsieh J, Fortier S, Li M, Yuan S, Birman E, Forner K, Boivin MN, Doody K, Tremblay M, Annabi B, Galipeau J. Mesenchymal stromal cell-derived CCL2 suppresses plasma cell immunoglobulin production via STAT3 inactivation and PAX5 induction. Blood. 2008, 112(13), 4991-4998.

[163] Schena F, Gambini C, Gregorio A, Mosconi M, Reverberi D, Gattorno M, Casazza S, Uccelli A, Moretta L, Martini A, Traggiai E. Interferon-gamma-dependent inhibition of $\mathrm{B}$ cell activation by bone marrow-derived mesenchymal stem cells in a murine model of systemic lupus erythematosus. Arthritis Rheum. 2010, 62(9), 2776-2786.

[164] Tabera S, Perez-Simon JA, Diez-Campelo M, Sanchez-Abarca LI, Blanco B, Lopez A, Benito A, Ocio E, Sanchez-Guijo FM, Canizo C, San Miguel JF. The effect of mesenchymal stem cells on the viability, proliferation and differentiation of B-lymphocytes. Haematologica. 2008, 93(9), 1301-1309.

[165] Youd M, Blickarz C, Woodworth L, Touzjian T, Edling A, Tedstone J, Ruzek M, Tubo R, Kaplan J, Lodie T. Allogeneic mesenchymal stem cells do not protect NZBxNZW F1 mice from developing lupus disease. Clin Exp Immunol. 2010, 161(1), 176-186.

[166] Koc ON, Gerson SL, Cooper BW, Dyhouse SM, Haynesworth SE, Caplan AI, Lazarus HM. Rapid hematopoietic recovery after coinfusion of autologous-blood stem cells and culture-expanded marrow mesenchymal stem cells in advanced breast cancer patients receiving high-dose chemotherapy. J Clin Oncol. 2000, 18(2), 307-316.

[167] Lazarus HM, Koc ON, Devine SM, Curtin P, Maziarz RT, Holland HK, Shpall EJ, McCarthy P, Atkinson K, Cooper BW, Gerson SL, Laughlin MJ, Loberiza FR, Jr., Moseley AB, Bacigalupo A. Cotransplantation of HLA-identical sibling culture-expanded mesenchymal stem cells and hematopoietic stem cells in hematologic malignancy patients. Biol Blood Marrow Transplant. 2005, 11(5), 389-398. 